Randomized Trial

\title{
One-Year Results of a Randomized, Double-Blind, Active Controlled Trial of Fluoroscopic Caudal Epidural Injections With or Without Steroids in Managing Chronic Discogenic Low Back Pain Without Disc Herniation or Radiculitis
}

Laxmaiah Manchikanti, MD'1, Kimberly A. Cash, RT'1, Carla D. McManus, RN, BSN', Vidyasagar Pampati, MSc', and Howard S. Smith, MD²

From: 'Pain Management Center of Paducah, Paducah, KY; and ${ }^{2}$ Albany Medical College, Albany, NY

Dr. Manchikanti is Medical Director of the Pain Management Center of Paducah, Paducah, KY and Associate Clinical Professor, Anesthesiology and Perioperative Medicine, University of Louisville, Louisville, KY

Ms. Cash is a Research Coordinator at the Pain Management Center of Paducah, Paducah, KY Mr. Pampati is a Statistician at the Pain Management Center of Paducah, Paducah, KY

Ms. McManus is a Nursing Administrator at the Pain Management Center of Paducah, Paducah, KY

Dr. Smith is Associate Professor and Academic Director of

Pain Management for Albany Medical College Department of

Anesthesiology, Albany, NY

Address Correspondence: Laxmaiah Manchikanti, M.D. 2831 Lone Oak Road

Paducah, Kentucky 42003 E-mail: drIm@thepainmd.com

Disclaimer: There was no external funding in the preparation of this manuscript.

Conflict of interest: None.

Manuscript received: 01/07/11 Accepted for publication: 01/11/11

Free full manuscript: www.painphysicianjournal.com
Background: Lumbar radicular pain pathophysiology continues to be the subject of research and debate as discogenic pain is increasingly seen as a cause of non-specific low back pain. Among non-surgical methods used to manage chronic low back pain with or without disc herniation, epidural injections are one of the most common modalities. However, there is little evidence utilizing contemporary methodology for using epidural injections in patients with discogenic pain.

Study Design: A randomized, double-blind, active-controlled trial.

Setting: An interventional pain management practice, a specialty referral center, a private practice setting in the United States.

Objectives: To evaluate the effectiveness of caudal epidural injections with local anesthetic, with or without steroids, in managing chronic low back pain without disc herniation or radiculitis.

Methods: A total of 120 patients were assigned to one of 2 groups. Group I patients received caudal epidural injections with local anesthetic (lidocaine $0.5 \% 10 \mathrm{~mL}$ ); Group II patients received caudal epidural injections with $9 \mathrm{~mL}$ of $0.5 \%$ lidocaine mixed with $1 \mathrm{~mL}$ of steroid (either brand name or non-particulate betamethasone [ $6 \mathrm{mg}$ ] or methylprednisolone [ $40 \mathrm{mg}$ ]. Computer-generated randomization and random allocation sequence by simple randomization were the randomization techniques utilized.

Outcomes Assessment: Multiple outcome measures were utilized which included the Numeric Rating Scale (NRS), the Oswestry Disability Index 2.0 (ODI), employment status, functional status, and opioid intake at 3, 6, and 12 months post treatment. Significant pain relief and functional status improvement were described as a $50 \%$ or more reduction in scores from baseline.

Results: Significant pain relief and functional status improvement were observed in $55 \%$ of the patients in Group I and 68\% of the patients in Group II. In contrast, 84\% of patients in Group I and $85 \%$ in Group II saw significant pain relief and functional status improvement in the successful group (62\% in Group I and 68\% in Group II). The average procedures per year were $3.8 \pm 0.9$ for Group I and $4.3 \pm 0.9$ for Group II. Average pain scores decreased from $8.0 \pm 0.9$ to $4.3 \pm 1.79$ for Group I and from $7.9 \pm 1.0$ to $3.8 \pm 1.59$ for Group II. There were no differences among the patients receiving one of the 3 steroids.

Limitations: The results of this study are limited by lack of a placebo group.

Conclusion: Caudal epidural injections with local anesthetic with or without steroids are effective in patients with chronic low back pain of discogenic origin without facet joint pain, disc herniation, and/or radiculitis.

Clinical Trial: NCT00370799

Key words: Chronic low back pain, lower extremity pain, discogenic pain, facet joint pain, disc herniation, radiculitis, lumbar interlaminar epidural injections, epidural steroids, local anesthetic

Pain Physician 2011; 14:25-36 
n 1934, Mixter and Barr (1) described lumbar disc herniation as causative for low back and lower extremity pain. The next year, Mixter and Ayers (2) showed that radicular pain can occur without disc herniation. Subsequently, many researchers (3-11) have described pain syndromes coming from lumbar intervertebral discs even though these discs were not compressing neural structures. Even then, the pathophysiology of spinal radicular pain continues to be investigated and debated and no causal relationship has been established between disc degeneration and spinal pain (7). However, numerous studies support chemical nociception leading to low back pain without disc herniation. Elevated levels of nitric oxide, prostaglandin E2, interleukin (IL)-2, IL-6, IL8, phospholipase A2, leukotriene B4, thromboxane B2, and tumor necrosis factor $-\alpha$ (TNF- $\alpha$ ) in diseased intervertebral discs have been demonstrated (12-19). Internal disc disruption (IDD) occurs when the internal architecture of the disc is disrupted, but its external appearance remains essentially normal (20). IDD can be experimentally induced by endplate damage (21). Adverse and progressive mechanical changes in the disc have been shown to result from experimentally induced annular tears $(21,22)$.

The cause of low back pain specifically of discogenic origin when there is no disc herniation and neurological deficit is absent, might not be possible to identify using magnetic resonance imaging (MRI), computed axial tomographic scanning (CT), neurophysiological testing, and comprehensive physical examination (3$5,8-11,23,24)$. In participants suffering with chronic low back pain, when utilizing controlled diagnostic blocks, the prevalence of pain due to IDD has been reported to be $39 \%$ (5) and primary discogenic pain has been reported in $26 \%$ (4) when no other cause was suspected. In the absence of disc herniation or radicular pain, facet joint pain has been shown to be present $21 \%$ to $40 \%$ of the time $(8,10,23)$; sacroiliac joint pain has been established in $10 \%$ to $27 \%$ of the population $(8,10,24)$.

In the United States, a commonly performed intervention for managing low back pain, including discogenic pain, is epidural injection $(8,11,25-37)$. This study sought to evaluate the role of caudal epidural injections in participants with chronic low back pain without disc herniation or radiculitis and those shown to be negative for facet joint pain by using controlled comparative local anesthetic blocks. This report including 120 participants is a one-year follow-up report of a previous publication (34).

\section{Methods}

The following study was conducted in the United States in a private interventional pain practice and specialty referral center based on Consolidated Standards of Reporting Trials (CONSORT) guidelines (38-40). The Institutional Review Board (IRB) approved the study protocol. The study is registered with the U.S. Clinical Trial Registry, number NCT00370799.

\section{Participants}

A total of 120 participants were assigned to one of 2 groups. Group I participants received caudal epidural injections with local anesthetic (lidocaine $0.5 \% 10 \mathrm{~mL}$ ); Group II participants received caudal epidural injections with $9 \mathrm{~mL}$ of $0.5 \%$ lidocaine mixed with $1 \mathrm{~mL}$ of steroid (either brand name or non-particulate betamethasone [6 $\mathrm{mg}$ ] or methylprednisolone [40 mg]. Each injection was flushed with a $2 \mathrm{~mL}$ solution of $0.9 \%$ sodium chloride solution.

\section{Interventions}

Participants received the IRB-approved protocol and informed consent, detailing all aspects of the study and the withdrawal process.

\section{Pre-Enrollment Evaluation}

Controlled comparative local anesthetic blocks were performed during a pre-enrollment evaluation to exclude facet joint pain. Patient demographic data, medical and surgical history with co-existing disease(s), radiologic investigations, physical examination, pain rating scores using the Numeric Rating Scale (NRS), work status, opioid intake, and functional status assessment by Oswestry Disability Index 2.0 (ODI) were also gathered.

\section{Inclusion Criteria}

Inclusion criteria used were: no evidence of disc herniation; negative diagnosis of lumbar facet joint pain by means of controlled local anesthetic blocks; at least 18 years of age; a history of chronic function-limiting low back pain of at least 6 months duration; participants competent to understand the study protocol and provide voluntary, written, informed consent as well as participate in outcome measurements; and failure to improve substantially with conservative management, including but not limited to physical therapy, chiropractic manipulation, exercises, drug therapy, and bedrest.

\section{Exclusion Criteria}

Exclusion criteria were: facet joint pain; previous lum- 
bar surgery; uncontrolled or unstable opioid use; uncontrolled psychiatric disorders; uncontrolled medical illnesseither acute or chronic; any other conditions that could interfere with the interpretation of outcome assessments, including: pregnant or lactating women and participants with a history or potential for an adverse reaction or reactions to either local anesthetics, steroids, or both.

\section{Description of Interventions}

Controlled comparative local anesthetic facet joint nerve blocks were performed on all participants. First, diagnostic facet joint nerve blocks were conducted with $0.5 \mathrm{~mL}$ of $1 \%$ lidocaine. Then, on separate occasions, blockade of facet joint nerves was conducted with $0.25 \%$ bupivacaine $(23,41)$. A response was considered negative if pain relief lasted less than 2 hours following the lidocaine injection, and lasted less than 3 hours or less than the duration of relief with lidocaine when bupivacaine was used.

A physician in a sterile operating room located in an ambulatory surgery setting, using fluoroscopy, performed the caudal epidural procedures. Participants were in the prone position and were monitored appropriately with intravenous access and sedation using midazolam and fentanyl. After sterile preparation, with confirmation of access to the epidural space by injection of non-ionic contrast, the assigned solution was injected.

\section{Additional Interventions}

Treatments were given to participants as assigned. Upon request, or if an emergency situation arose, a patient would be unblinded. Based on a patient's response to prior caudal epidural injections and the improvement in physical and functional status, repeat caudal epidural injections were performed when increased levels of pain were reported with deteriorating relief below $50 \%$. Nonresponsive participants treated with conservative management were followed without further epidural injections with medical management, without unblinding.

\section{Co-Interventions}

Nearly all participants were undergoing conservative management before joining the study. These treatments included analgesics (adjuvant, opioid, and non-opioid) and/or a therapeutic exercise program. Participants who showed substantial improvement and no longer needed drugs had their drugs decreased or ended; if needed, dosages were increased. Exercising and job attendance continued. The study intervention was the only new treatment introduced.

\section{Objectives}

The study investigated caudal epidural injections' (with or without steroids) value in managing chronic low back pain (without disc herniation or radiculitis); their effective and long-lasting pain relief; and also investigated the efficacy of local anesthetic with and without steroid.

\section{Outcomes}

Measurable outcomes employed were: NRS pain scale $(0-10$, with 0 as no pain and 10 as worst pain imaginable); ODI (0-50) for functional assessment; employment status; and morphine-equivalent opioid use at 3, 6, and 12 months after treatment.

NRS's and ODI's value and validity are established $(39,40,42-44)$. The ODI minimum clinically important difference threshold varied from 4-15 points (total score of 50). A $50 \%$ or more reduction in NRS from baseline signified significant pain relief. At least a 50\% reduction in the ODI described significant improvement and function, a measure incorporating a higher robust standard $(34,39,40,42-44)$. Morphine equivalents were substituted for opioid intake (45).

The criterion for work status was based on the time of enrollment. Employment categories included: employable, housewife with no desire to work outside the home, retired, and over age 65 . Those unemployed because of pain, on sick leave, or laid off were considered employable.

\section{Sample Size}

The sample size was calculated based on significant pain relief. Considering a 0.05 two-sided significance level, a power of $80 \%$, and an allocation ratio of 1:1, 55 participants in each group were estimated (46). Allowing for a $10 \%$ attrition/ non-compliance rate, 60 participants were required.

\section{Randomization}

Each group was randomly assigned 60 participants from 120 selected.

\section{Sequence Generation}

Computer-generated random allocations sequence by simple randomization was performed.

\section{Allocation Concealment}

Patient randomization and drug preparation was done by the nurse coordinator, without knowledge of patient, physician, or other personnel. 


\section{Implementation}

All participants meeting inclusion criteria were invited to participate. They were enrolled and assigned to a group by a nurse coordinator.

\section{Blinding (Masking)}

Group assignments were blinded to participants and intervention performers. Study participants were mixed with routine treatment participants. A statistician not involved with patient care assembled the data. Blinding was not interrupted because treating physicians, participants, and participants did not know the unblinding results.

\section{Statistical Methods}

Chi-squared statistic, Fisher's exact test, one-way analysis of variance (ANOVA), t-test, and paired t-test were the statistical analyses used. If the $P$ value was less than 0.05 , results were considered statistically significant.

Differences in proportions were tested by chisquared statistic. ANOVA is used to compare means of 2 or more samples. Whenever an expected value was less than 5, Fisher's exact test was used. The pre- and posttreatment results of average pain scores and ODI measurements at baseline and 3, 6, and 12 months were compared with a paired t-test. T-test compared mean scores among groups.

Initially, 3 subgroups of participants receiving steroids in Group II were analyzed for any differences. If no significant differences were observed, the results were presented as a single group.

\section{Intent-to-Treat-Analysis}

A sensitivity analysis with changes in the NRS was performed utilizing the last follow-up score, best case scenario, and worst case scenario if there were no significant differences; the intention-to-treat analysis with last follow-up visit was used.

\section{Results}

\section{Participant Flow}

Figure 1 illustrates the participant flow.

\section{Recruitment}

Enrollment period lasted from January 2007 to August 2008.

\section{Baseline Data}

Table 1 shows baseline characteristics.

\section{Analysis of Data}

Intention-to-treat analysis was carried out by last follow-up data, as there were no differences noted with sensitivity analysis.

\section{Therapeutic Procedural Characteristics}

The epidural injections were considered successful if: the patient got relief from the first injection of at least one week, the second injection at least 3 weeks, and the second injection relief exceeded the first injection. A failure was any other result.

Table 2 illustrates these results. Group I had an average overall pain relief of $28.2 \pm 18.8$ weeks; Group II was

Table 1. Baseline demographic characteristics.

\begin{tabular}{|c|c|c|c|c|}
\hline & & Group 1 (60) & Group II (60) & $P$ value \\
\hline \multirow{2}{*}{ Gender } & Male & $22 \%(13)$ & $37 \%(22)$ & \multirow{2}{*}{0.071} \\
\hline & Female & $78 \%(47)$ & $63 \%(38)$ & \\
\hline Age & Mean \pm SD & $48.5 \pm 15.3$ & $43.9 \pm 13.1$ & 0.08 \\
\hline Weight & Mean \pm SD & $189.5 \pm 59.6$ & $177.1 \pm 42.5$ & 0.190 \\
\hline Height & Mean \pm SD & $64.8 \pm 3.7$ & $66.3^{*} \pm 3.6$ & 0.025 \\
\hline Duration of Pain (months) & Mean \pm SD & $100 \pm 87.0$ & $92 \pm 85.4$ & 0.611 \\
\hline \multirow{2}{*}{ Onset of the Pain } & Gradual & $70 \%(42)$ & $60 \%(36)$ & \multirow{2}{*}{0.339} \\
\hline & Injury & $30 \%(18)$ & $40 \%(24)$ & \\
\hline \multirow{2}{*}{ Low Back Pain Distribution } & Bilateral & $83 \%(50)$ & $83 \%(50)$ & \multirow{2}{*}{1.000} \\
\hline & Left or Right & $17 \%(10)$ & $17 \%(10)$ & \\
\hline Numeric Rating Score & Mean \pm SD & $8.0 \pm 0.9$ & $7.9 \pm 1.0$ & 0.374 \\
\hline Oswestry Disability Index & Mean \pm SD & $28.3 \pm 4.92$ & $28.4 \pm 4.67$ & 0.939 \\
\hline
\end{tabular}

${ }^{*}$ Significant difference 


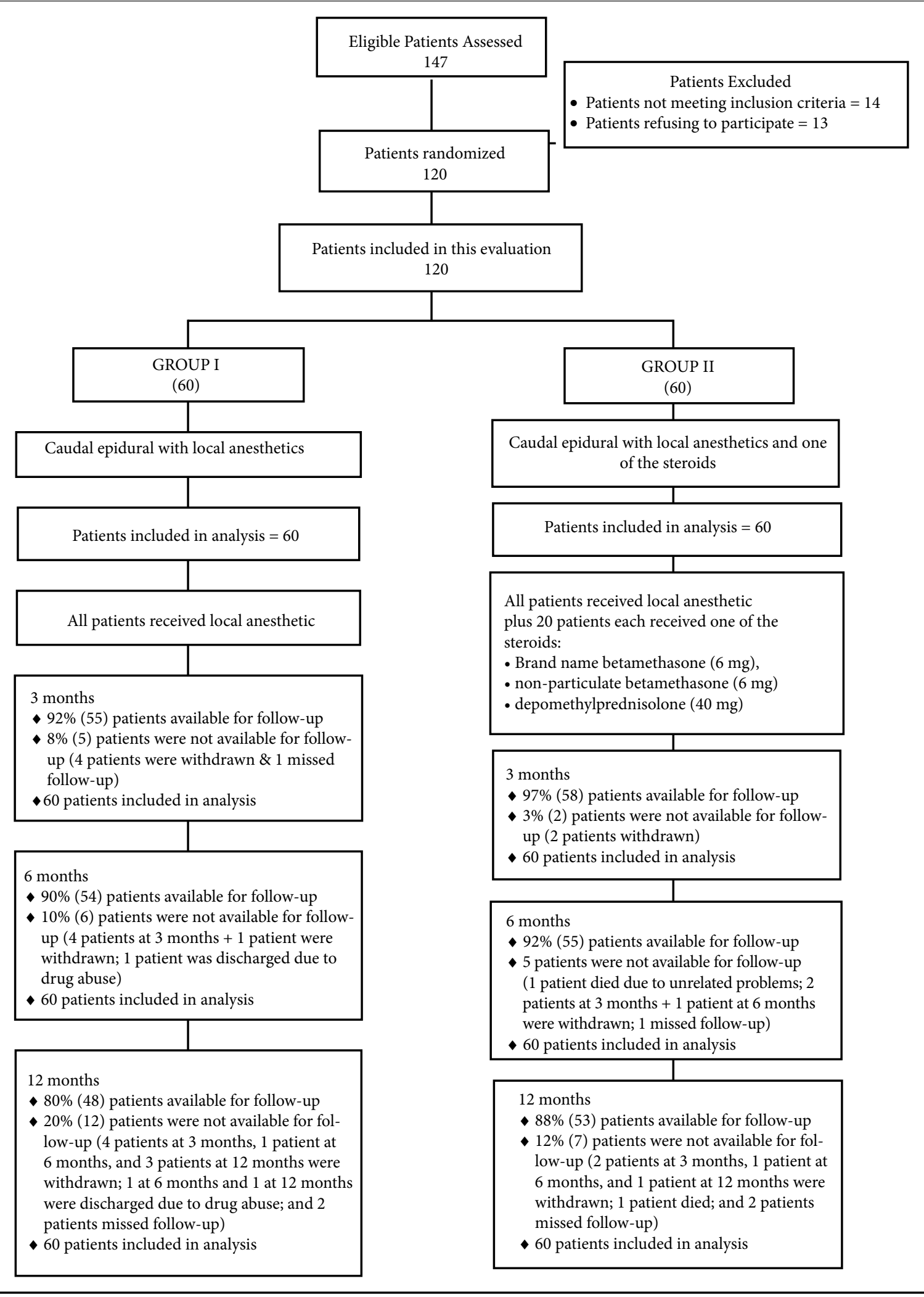

Fig. 1. Schematic presentation of patient flow at 1-year follow-up 
Table 2. Therapeutic procedural characteristics with procedural frequency, average relief per procedure, and average total relief in weeks over a period of 1-year.

\begin{tabular}{|c|c|c|c|c|c|c|}
\hline & \multicolumn{2}{|c|}{ Successful participants } & \multicolumn{2}{|c|}{ Failed participants } & \multicolumn{2}{|c|}{ Combined } \\
\hline & $\begin{array}{l}\text { Group I } \\
(37)\end{array}$ & $\begin{array}{l}\text { Group II } \\
(41)\end{array}$ & $\begin{array}{c}\text { Group I } \\
(23)\end{array}$ & $\begin{array}{c}\text { Group II } \\
\text { (19) }\end{array}$ & $\begin{array}{c}\text { Group I } \\
(\mathbf{6 0})\end{array}$ & $\begin{array}{l}\text { Group II } \\
(\mathbf{6 0})\end{array}$ \\
\hline 1st procedure relief & $\begin{array}{c}7.1 \pm 6.8 \\
(37)\end{array}$ & $\begin{array}{c}6.6 \pm 3.9 \\
(41)\end{array}$ & $\begin{array}{l}2.3 \pm 2.3 \\
(23)\end{array}$ & $\begin{array}{l}1.5 \pm 2.4 \\
(19)\end{array}$ & $\begin{array}{l}5.3 \pm 5.9 \\
(60)\end{array}$ & $\begin{array}{l}5.0 \pm 4.2 \\
60)\end{array}$ \\
\hline 2nd procedure relief & $\begin{array}{l}12.1 \# \pm 5.2 \\
\quad(37)\end{array}$ & $\begin{array}{l}11.1 \pm 7.8 \\
\quad(41)\end{array}$ & $\begin{array}{l}1.4 \pm 1.6 \\
\quad(17)\end{array}$ & $\begin{array}{l}1.9 \pm 2.1 \\
(16)\end{array}$ & $\begin{array}{c}8.7 \pm 6.7 \\
(54)\end{array}$ & $\begin{array}{c}8.5 \pm 7.9 \\
(57)\end{array}$ \\
\hline 3rd procedure relief & $\begin{array}{l}13.1+5.0 \\
(34)\end{array}$ & $\begin{array}{l}11.7 \pm 4.1 \\
(38)\end{array}$ & $\begin{array}{c}3.8 \pm 3.9 \\
(10)\end{array}$ & $\begin{array}{l}7.4 \pm 5.1 \\
(10)\end{array}$ & $\begin{array}{l}11.0 \pm 6.2 \\
\quad(44)\end{array}$ & $\begin{array}{c}10.8 \pm 4.6 \\
(48)\end{array}$ \\
\hline 4th procedure relief & $\begin{array}{l}11.7+2.1 \\
(22)\end{array}$ & $\begin{array}{l}11.4 \pm 3.2 \\
\quad(34)\end{array}$ & $\begin{array}{c}6.1 \pm 3.4 \\
(6)\end{array}$ & $\begin{array}{c}8.6 \pm 4.7 \\
\quad(8)\end{array}$ & $\begin{array}{l}10.5 \pm 3.3 \\
(28)\end{array}$ & $\begin{array}{c}10.9 \pm 3.7 \\
(42)\end{array}$ \\
\hline 5th procedure relief & $\begin{array}{l}11.7+2.4 \\
(10)\end{array}$ & $\begin{array}{l}11.3 \pm 3.5 \\
(20)\end{array}$ & $\begin{array}{l}8.0+4.2 \\
(2)\end{array}$ & $\begin{array}{l}7.6+3.0 \\
(5)\end{array}$ & $\begin{array}{l}11.1 \pm 2.9 \\
\quad(12)\end{array}$ & $\begin{array}{l}10.5 \pm 3.7 \\
(25)\end{array}$ \\
\hline $\begin{array}{l}\text { Number of procedures } \\
\text { per year }\end{array}$ & $\begin{array}{c}3.8 \# \pm 0.9 \\
(37)\end{array}$ & $\begin{array}{c}4.3 \pm 0.9 \\
(41)\end{array}$ & $\begin{array}{c}2.5 \pm 1.3 \\
(23)\end{array}$ & $\begin{array}{c}3.1 \pm 1.6 \\
(19)\end{array}$ & $\begin{array}{c}3.3 \# \pm 1.3 \\
(60)\end{array}$ & $\begin{array}{c}3.9 \pm 1.3 \\
(60)\end{array}$ \\
\hline $\begin{array}{l}\text { Average relief per } \\
\text { procedure }\end{array}$ & $\begin{array}{c}11.2 \pm 3.5 \\
(37)\end{array}$ & $\begin{array}{l}10.5 \pm 3.6 \\
(41)\end{array}$ & $\begin{array}{c}2.5 \pm 2.3 \\
(23)\end{array}$ & $\begin{array}{l}3.1 \pm 2.8 \\
(19)\end{array}$ & $\begin{array}{l}10.9 \pm 3.5 \\
(60)\end{array}$ & $\begin{array}{c}2.8 \pm 2.5 \\
(60)\end{array}$ \\
\hline $\begin{array}{l}\text { Total relief per year } \\
\text { (weeks) }\end{array}$ & $\begin{array}{l}40.8 \pm 9.4 \\
(37)\end{array}$ & $\begin{array}{l}43.1 \pm 10.2 \\
\quad(41)\end{array}$ & $\begin{array}{l}7.9 \pm 10.4 \\
(23)\end{array}$ & $\begin{array}{c}12.9 \pm 13.9 \\
(19)\end{array}$ & $\begin{array}{l}28.2 \pm 18.8 \\
\quad(60)\end{array}$ & $\begin{array}{c}33.5 \pm 18.2 \\
(60)\end{array}$ \\
\hline
\end{tabular}

\# indicates significant difference with Group II $(P<0.05)$

Successful participant - At least one week relief at first procedure and $\geq 4$ weeks relief at second procedure

$33.5 \pm 18.2$ weeks. However, when participants were separated into successful and failed groups, the total number of procedures per year was $3.8 \pm 0.9$ in Group I and $4.3 \pm$ 0.9 in Group II for successful participants with relief of 40.8 \pm 9.4 weeks in Group I and $43.1 \pm 10.2$ weeks in Group II with 37 of 60 participants or $62 \%$ in Group I and 41 of 60 participants or $68 \%$ in Group II. In contrast, in failed participants the number of procedures per year was $2.5 \pm 1.3$ in Group I and $3.1 \pm 1.6$ in Group II with total relief of $7.9 \pm$ 10.4 weeks in Group I and $12.9 \pm 13.9$ weeks in Group II.

There were significant differences in the number of procedures per year with greater number of procedures in Group II compared to Group I.

\section{Outcomes}

\section{Pain Relief}

NRS scores are shown in Table 3. At 12 months, $63 \%$ of participants in Group I and $72 \%$ of participants in Group II showed significant pain relief.

\section{Functional Assessment}

ODI functional assessment results are shown in Table 4. At 12 months, 55\% in Group I and 72\% in Group II showed significant improvement.
Table 3. Pain relief characteristics.

\begin{tabular}{||l|c|c|r||}
\hline \multirow{2}{*}{$\begin{array}{c}\text { Numeric } \\
\text { Rating Score }\end{array}$} & Group I (60) & Group II (60) & \multirow{2}{*}{ P value } \\
\cline { 2 - 3 } & Mean \pm SD & Mean \pm SD & \\
\hline Baseline & $8.0 \pm 0.9$ & $7.9 \pm 1.0$ & 0.374 \\
\hline 3 months & $4.2^{*} \pm 1.76$ & $3.6^{*} \pm 1.40$ & 0.061 \\
\hline 6 months & $4.1^{*} \pm 1.83$ & $3.7^{*} \pm 1.46$ & 0.171 \\
\hline 12 months & $4.3^{*} \pm 1.79$ & $3.8^{*} \pm 1.59$ & 0.134 \\
\hline
\end{tabular}

${ }^{*}$ indicates significant difference with baseline values $(P<0.001)$

Table 4. Functional assessment evaluated by Oswestry Disability Index.

\begin{tabular}{|l|l|l|r|}
\hline $\begin{array}{c}\text { Oswestry Disability } \\
\text { Index }\end{array}$ & \multicolumn{1}{c|}{$\begin{array}{c}\text { Group I } \\
(\mathbf{6 0})\end{array}$} & $\begin{array}{c}\text { Group II } \\
(\mathbf{6 0})\end{array}$ & P value \\
\hline & Mean \pm SD & Mean \pm SD & \\
\hline Baseline & $28.3 \pm 4.92$ & $28.4 \pm 4.67$ & 0.939 \\
\hline 3 months & $16.3^{*} \pm 7.23$ & $14.5^{*} \pm 5.51$ & 0.121 \\
\hline 6 months & $16.2^{*} \pm 7.81$ & $14.3^{*} \pm 5.87$ & 0.125 \\
\hline 12 months & $15.4^{*} \pm 6.46$ & $14.5^{*} \pm 6.05$ & 0.129 \\
\hline
\end{tabular}

* indicates significant difference with baseline values $(P<0.001)$ 


\section{G Group I 圆 Group II}

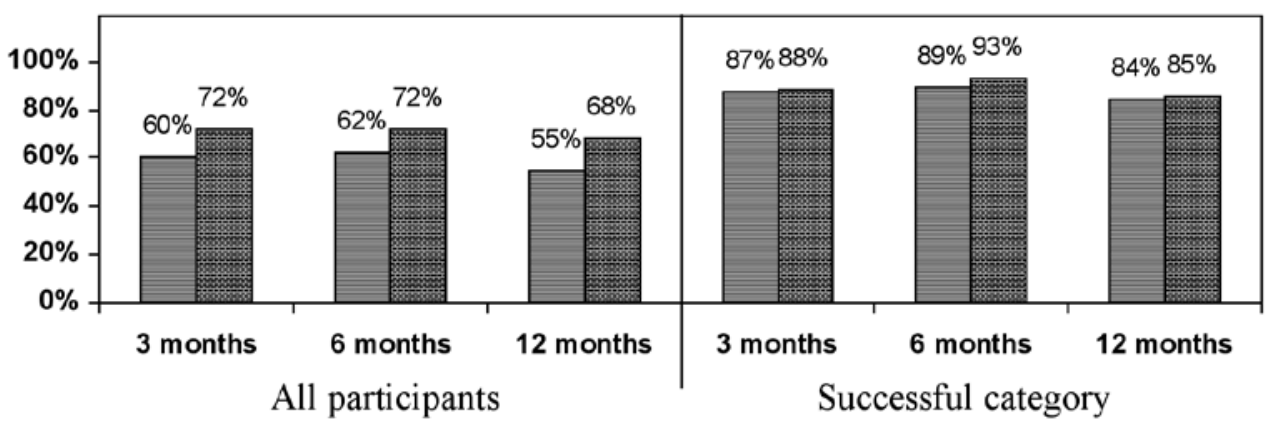

Fig. 2. Proportion of participants with significant reduction in Numeric Rating Score and Oswestry Disability Index $(\geq=50 \%$ reduction from baseline).

\section{Pain Relief and Functional Improvement}

Figure 2 illustrates the proportion of participants with significant change in pain and function. This is illustrated in overall participants with $55 \%$ in Group I and $68 \%$ in Group II at 12 months. However, the data from the successful group showed improvement with $84 \%$ in Group I and 85\% in Group II at 12 months.

\section{Employment Characteristics}

Employment characteristics are shown in Table 5.

\section{Opioid Intake}

Opioid intake is illustrated in Table 6.

\section{Changes in Weight}

Table 7 shows no significant weight change in either group.

\section{Adverse Events}

No participants reported significant adverse effects during the study period.

Table 6. Opioid intake (morphine equivalence mg)

\begin{tabular}{||c|c|c|r||}
\hline $\begin{array}{c}\text { Opioid intake } \\
\text { (Morphine } \\
\text { Equivalence mg) }\end{array}$ & $\begin{array}{c}\text { Group I } \\
(\mathbf{6 0})\end{array}$ & $\begin{array}{c}\text { Group II } \\
(\mathbf{6 0})\end{array}$ & $\begin{array}{c}\boldsymbol{P} \\
\text { value }\end{array}$ \\
\cline { 2 - 3 } & Mean \pm SD & Mean \pm SD & \\
\hline Baseline & $34.5 \pm 33.7$ & $36.2 \pm 19.8$ & 0.725 \\
\hline 3 months & $28.7 \# \pm 27.1$ & $29.9 \# \pm 19.9$ & 0.789 \\
\hline 6 months & $31.5 \pm 38.4$ & $31.0 \pm 19.9$ & 0.929 \\
\hline 12 months & $31.5 \pm 38.4$ & $30.0 \# \pm 19.9$ & 0.789 \\
\hline
\end{tabular}

\# indicates significant difference with baseline values $(P<0.05)$
Table 5. Employment characteristics.

\begin{tabular}{|l|c|c|c|c|}
\hline \multirow{2}{*}{$\begin{array}{l}\text { Employment } \\
\text { status }\end{array}$} & \multicolumn{2}{|c|}{ Group I } & \multicolumn{2}{c|}{ Group II } \\
\cline { 2 - 5 } & Baseline & $\begin{array}{c}\mathbf{1 2} \\
\text { months }\end{array}$ & Baseline & $\begin{array}{c}\mathbf{1 2} \\
\text { months }\end{array}$ \\
\hline Employed part-time & 4 & 1 & 2 & 5 \\
\hline Employed full-time & 6 & 16 & 10 & 14 \\
\hline Unemployed & 6 & 2 & 8 & 3 \\
\hline $\begin{array}{l}\text { Eligible for } \\
\text { employment }\end{array}$ & 16 & 16 & 20 & 20 \\
\hline Total employed & 10 & 17 & 12 & 19 \\
\hline Housewife & 7 & 5 & 5 & 3 \\
\hline Disabled & 29 & 28 & 33 & 33 \\
\hline Over 65 years of age & 8 & 8 & 2 & 2 \\
\hline $\begin{array}{c}\text { Total Number of } \\
\text { Participants }\end{array}$ & $\mathbf{6 0}$ & $\mathbf{6 0}$ & $\mathbf{6 0}$ & $\mathbf{6 0}$ \\
\hline
\end{tabular}

Table 7. Characteristics of changes in weight.

\begin{tabular}{|c|c|c|c|}
\hline \multirow{2}{*}{ Weight (lbs) } & Group I (60) & "Group II (60) & \multirow{2}{*}{$\begin{array}{c}P \\
\text { value }\end{array}$} \\
\hline & Mean \pm SD & Mean \pm SD & \\
\hline Weight at beginning & $189.5 \pm 59.6$ & $177.1 \pm 42.5$ & 0.191 \\
\hline Weight at one year & $187.2 \pm 58.7$ & $177.1 \pm 42.9$ & 0.281 \\
\hline Change & $-2.3 \pm 9.1$ & $0 \pm 9.5$ & 0.181 \\
\hline Lost weight & $28 \%(17)$ & $45 \%(27)$ & \multirow{3}{*}{0.163} \\
\hline No change & $23 \%(14)$ & $17 \%(10)$ & \\
\hline Gained weight & $48 \%(29)$ & $38 \%(23)$ & \\
\hline
\end{tabular}




\section{Discussion}

One year results of this study of 120 participants showed significant pain relief and functional status improvement $(\geq 50 \%$ ) in $55 \%$ of the participants in Group I and $68 \%$ of the participants in Group II. However, if only pain relief were taken into consideration, $63 \%$ of Group I participants experienced significant pain relief and $72 \%$ of Group II participants experienced significant pain relief. Further, after separating the individuals into successful and failed groups, in the successful group (62\% in Group I and 68\% in Group II), $84 \%$ in Group I and $85 \%$ in Group II experienced significant pain relief associated with functional status improvement. The average procedures per year in the successful group were $3.8 \pm 0.9$ in Group I and $4.3 \pm 0.9$ in Group II with an average total relief per year of $40.8 \pm 9.4$ weeks in Group I and $43.1 \pm 10.2$ weeks in Group II over a period of 52 weeks. However, the overall total relief per year was $28.2 \pm 18.8$ in Group I and $33.5 \pm 18.2$ weeks in Group II among all subjects with very low response in failed subjects. There were no differences among these participants receiving any of the 3 steroids.

The results of this study illustrate that if the response is fair to poor with the first 2 procedures, they will continue to exhibit a poor response with future treatments. Both pain relief and improvement in functional status are clinically and statistically significant. Strict criteria were incorporated into the study and the participants only judged not to have facet joint pain were included in the study, thus avoiding the criticism that including those with facet joint pain in a study contributes to negative results.

There is significant debate with regards to medical necessity and indications for lumbar epidural injections either by the interlaminar approach or caudal approach. Multiple systematic reviews, guidelines, and other reviews have identified indications for caudal epidural injections in positive reports to treat radicular pain from herniated lumbar intervertebral discs. The evidence for other indications is limited. One preliminary report of a randomized trial $(34)$ and 2 observational studies $(35,36)$ have shown positive results in participants without disc herniation or radiculitis, but with chronic function-limiting low back pain. As confirmed in this report, epidural injections do not provide long-term relief. However, long-term relief can be achieved with judicious use and appropriate evaluation in patients without facet joint pain, in a select group of patients.

The results of this evaluation might be generalizable to interventional pain management settings with appropriate diagnostic techniques and under fluoroscopic visualization. This study may be considered a practical clinical trial. In the era of evidence-based medicine, and comparative effectiveness research $(8,1$ $1,27,28,39,40,42,43,47-50)$, pragmatic or practical clinical trials measuring effectiveness are considered more appropriate than explanatory trials measuring efficacy $(39,40,42,43,47-61)$. Explanatory trials measure efficacy, whereas pragmatic or practical trials are best designed to provide the results of the benefit of the treatment produced in routine clinical practice (62).

The study may be criticized for the lack of a placebo group and analysis at one year. Placebo-controlled neural blockade is not realistic even though it has been misinterpreted (63). Some have mistakenly reported that any local anesthetic injection which yields similar results as steroids is considered a placebo. The experimental and clinical findings from investigation of the electrophysiological effects of $0.9 \%$ sodium chloride and dextrose $5 \%$ in water solution have illustrated potential inaccuracy created by $0.9 \%$ sodium chloride solution versus $5 \%$ dextrose $(64,65)$. Further, the evidence also has shown differing effects of sodium chloride solution when injected into either the disc, the facet joint or paraspinal muscles, with interaction between the porcine lumbar intervertebral disc, zygapophysial joints, and paraspinal muscles $(66,67)$. They showed that the introduction of lidocaine or physiologic saline into the zygapophysial joint reduced the stimulation pathway from the intervertebral disc to the paraspinal musculature $(66,67)$. Consequently, they hypothesized that the paraspinal muscle activation caused by nerve stimulation in the annulus fibrosus of a lumbar intervertebral disc could be altered by saline injection into the zygapophysial joint. Further, epidural saline has been shown to be active and therapeutic (68-70). Finally, for placebo effect to be evident it has to be non-existent with prior treatments, and present repeatedly.

The underlying mechanism of action of epidurally administered steroid and local anesthetic injection is still not well understood. It is believed that the achieved neural blockade alters or interrupts nociceptive input, the reflex mechanism of the afferent fibers, self-sustaining activity of the neurons, and the pattern of central neuronal activities $(8,11,71)$. Further, corticosteroids have been shown to reduce inflammation by inhibiting either the synthesis or release of a number of pro-inflammatory mediators and by causing a reversible local anesthetic effect (71-76). Local anesthetics also have been described to provide short- to 
long-term symptomatic relief based on alteration of various mechanisms including excess nociceptive process, excess release of neurotransmitters, nociceptive sensitization of the nervous system, and phenotype changes (77-83). The prolonged effect of local anesthetics in epidural injections and facet joint nerve blocks has been demonstrated in a multiple of studies $(51-58,80,84,85)$. Sato et al $(86)$ evaluated the prolonged analgesic effect of epidural bupivacaine in a rat model of neuropathic pain with repetitive administration, possibly by inducing a plastic change in nociceptive input. Further, Tachihara et al (87) showed in rats that nerve root infiltration prevented mechanical allodynia; however, no additional benefit from using corticosteroid was identified.

The results of the present study describe participants in a private practice, interventional pain management setting. Consequently, the results are not applicable in the general population unless the same methodology is utilized with the diagnosis and therapy. Further, generalizability of the findings of this study might only be feasible in studies utilizing larger populations in multiple settings.

Overall, the evidence in this report demonstrates caudal epidural injections in participants negative for lumbar facet joint pain, without disc herniation or radiculitis, may be treated with caudal epidural injections with or without steroids, providing approximately 12 weeks of relief with each procedure and requiring 3-4 episodes of treatment per year.

\section{Conclusion}

The assessment of the one-year results of this randomized, double-blind, controlled trial of caudal epidural injections in chronic function-limiting low back pain without facet joint pain, disc herniation, and/or radiculitis demonstrated effectiveness in $84 \%$ of participants with local anesthetic only and $85 \%$ of participants with local anesthetic and steroids, with significant pain relief and improvement in functional status in the successful group.

\section{Acknowledgments}

The authors wish to thank Sekar Edem for assistance in the search of the literature, Tom Prigge for manuscript review, and Tonie M. Hatton and Diane E. Neihoff, transcriptionists, for their assistance in preparation of this manuscript. We would like to thank the editorial board of Pain Physician for review and criticism in improving the manuscript.

\section{References}

1. Mixter WJ, Barr JS. Rupture of the intervertebral disc with involvement of the spinal canal. N Eng J Med 1934; 211:210-215.

2. Mixter WJ, Ayers JB. Herniation or rupture of the intervertebral disc into the spinal canal. N Engl J Med 1935; 213:385-395.

3. Manchikanti L, Glaser S, Wolfer L, Derby $\mathrm{R}$, Cohen SP. Systematic review of lumbar discography as a diagnostic test for chronic low back pain. Pain Physician 2009; 12:541-559.

4. Manchikanti L, Singh V, Pampati V, Damron KS, Barnhill RC, Beyer CD, Cash $\mathrm{KA}$. Evaluation of the relative contributions of various structures in chronic low back pain. Pain Physician 2001; 4:308-316.

5. Schwarzer AC, Aprill CN, Derby R, Fortin J, Kine G, Bogduk N. The prevalence and clinical features of internal disc disruption in patients with chronic low back pain. Spine (Phila Pa 1976) 1995: 20:1878-1883.
6. Crock HV. A reappraisal of intervertebral disc lesions. Med J Aust 1970; 1:983989.

7. Wheeler AH, Murrey DB. Chronic lumbar spine and radicular pain: Pathophysiology and treatment. Curr Pain Headache Rep 2002; 6:97-105.

8. Manchikanti L, Boswell MV, Singh V, Benyamin RM, Fellows B, Abdi S, Buenaventura RM, Conn A, Datta S, Derby R, Falco FJE, Erhart S, Diwan S, Hayek SM, Helm S, Parr AT, Schultz DM, Smith HS, Wolfer LR, Hirsch JA. Comprehensive evidence-based guidelines for interventional techniques in the management of chronic spinal pain. Pain Physician 2009; 12:699-802.

9. Wolfer L, Derby R, Lee JE, Lee SH. Systematic review of lumbar provocation discography in asymptomatic subjects with a meta-analysis of false-positive rates. Pain Physician 2008; 11:513-538.

10. Manchikanti L, Boswell MV, Singh V, Derby R, Fellows B, Falco FJE, Datta $S$, Smith HS, Hirsch JA. Comprehensive review of neurophysiologic basis and diagnostic interventions in managing chronic spinal pain. Pain Physician 2009; 12:E71-E120.

11. Manchikanti L, Boswell MV, Datta S, Fellows B, Abdi S, Singh V, Benyamin RM, Falco FJE, Helm S, Hayek S, Smith HS. Comprehensive review of therapeutic interventions in managing chronic spinal pain. Pain Physician 2009; 12:E123E198.

12. Ahmed $M$, Bjurholm $A$, Kreicbergs $A$, Schultzberg M. Neuropeptide $Y$, tyrosine hydroxylase and vasoactive intestinal polypeptide-immunoreactive nerve fibers in the vertebral bodies, discs, dura mater, and spinal ligaments of the rat lumbar spine. Spine (Phila Pa 1976) 1993; 18:268-273.

13. Ashton IK, Eisenstein SM. The effect of substance $P$ on proliferation and proteoglycan deposition of cells derived from rabbit intervertebral disc. Spine (Phila Pa 1976) 1996; 21:421-426.

14. Kang JD, Stefanovic-Racic M, McIntyre 
LA, Georgescu HI, Evans CH. Toward a biochemical understanding of human intervertebral disc degeneration and herniation. Contributions of nitric oxide, interleukins, prostaglandin E2, and matrix metalloproteinases. Spine (Phila Pa 1976) 1997; 22:1065-1073.

15. Ohtori $S$, Inoue $G$, Ito $T$, Koshi T, Ozawa T, Doya H, Saito T, Moriya H, Takahashi K. Tumor necrosis factor-immunoreactive cells and PGP 9.5-immunoreactive nerve fibers in vertebral endplates of patients with discogenic low back pain and modictype 1 or type 2 changes on MRI. Spine (Phila Pa 1976) 2006; 31:1026-1031.

16. McCarron RF, Wimpee MW, Hudkins PG, Laros GS. The inflammatory effects of nucleus pulposus: A possible element in the pathogenesis of low back pain. Spine (Phila Pa 1976) 1987; 12:760764.

17. Aoki Y, Rydevik B, Kikuchi S, Olmarker K. Local application of disc-related cytokines on spinal nerve roots. Spine (Phila Pa 1976) 2002; 27:1614-1617.

18. Huang $K Y$, Lin RM, Chen WY, Lee $C L$, Yan $\mathrm{JJ}$, Chang MS. IL-20 may contribute to the pathogenesis of human intervertebral disc herniation. Spine (Phila Pa 1976) 2008; 33:2034-2040.

19. O'Neill CW, Kurgansky ME, Derby R, Ryan DP. Disc stimulation and patterns of referred pain. Spine (Phila Pa 1976) 2002; 27:2776-2781.

20. Crock HV. Isolated lumbar disc resorption as a cause of nerve root canal stenosis. Clin Orthop 1976; 115:109-115.

21. Holm S, Holm AK, Ekstrom L, Karladani A, Hansson T. Experimental disc degeneration due to endplate injury. I Spinal Disord Tech 2004; 17:64-71.

22. Videman $T$, Nurminen $M$. The occurrence of anular tears and their relation to lifetime back pain history: A cadaveric study using barium sulfate discography. Spine (Phila Pa 1976) 2004; 29:2668-2676.

23. Datta $S$, Lee $M$, Falco FJE, Bryce DA, Hayek SM. Systematic assessment of diagnostic accuracy and therapeutic utility of lumbar facet joint interventions. Pain Physician 2009; 12:437460.

24. Rupert MP, Lee M, Manchikanti L, Datta S, Cohen SP. Evaluation of sacroiliac joint interventions: A systematic appraisal of the literature. Pain Physician 2009; 12:399-418.
25. Staal JB, de Bie R, de Vet HC, Hildebrandt J, Nelemans $P$. Injection therapy for subacute and chronic low-back pain. Cochrane Database Syst Rev 2008; 3:CD001824.

26. Manchikanti L, Singh V, Derby R, Schultz DM, Benyamin RM, Prager JP, Hirsch JA. Reassessment of evidence synthesis of occupational medicine practice guidelines for interventional pain management. Pain Physician 2008; 11:393482.

27. Conn A, Buenaventura R, Datta S, Abdi $S$, Diwan S. Systematic review of caudal epidural injections in the management of chronic low back pain. Pain Physician 2009; 12:109-135.

28. Parr AT, Diwan S, Abdi S. Lumbar interlaminar epidural injections in managing chronic low back and lower extremity pain: A systematic review. Pain Physician 2009; 12:163-188.

29. Buenaventura RM, Datta S, Abdi $S$, Smith HS. Systematic review of therapeutic lumbar transforaminal epidural steroid injections. Pain Physician 2009; 12:233-251.

30. Chou R, Atlas SJ, Stanos SP, Rosenquist RW. Nonsurgical interventional therapies for low back pain: A review of the evidence for an American Pain Society clinical practice guideline. Spine (Phila Pa 1976) 2009; 34:1078-1093.

31. Manchikanti L, Pampati V, Boswell MV, Smith HS, Hirsch JA. Analysis of the growth of epidural injections and costs in the Medicare population: A comparative evaluation of 1997, 2002, and 2006 data. Pain Physician 2010; 13:199-212.

32. Manchikanti L, Singh V, Pampati V, Smith HS, Hirsch JA. Analysis of growth of interventional techniques in managing chronic pain in Medicare population: A 10-year evaluation from 1997 to 2006. Pain Physician 2009; 12:9-34.

33. Friedly J, Leighton C, Deyo R. Increases in lumbosacral injections in the Medicare population: 1994 to 2001. Spine (Phila Pa 1976) 2007; 32:1754-1760.

34. Manchikanti L, Cash KA, McManus CD, Pampati V, Smith HS. Preliminary results of randomized, equivalence trial of fluoroscopic caudal epidural injections in managing chronic low back pain: Part 1. Discogenic pain without disc herniation or radiculitis. Pain Physician 2008; 11:785-800.

35. Manchikanti L, Singh V, Rivera JJ, Pampati V, Beyer CD, Damron KS, Barnhill RC. Effectiveness of caudal epidural in- jections in discogram positive and negative chronic low back pain. Pain Physician 2002; 5:18-29.

36. Manchikanti L, Pampati V, Rivera JJ, Beyer CD, Damron KS, Barnhill RC. Caudal epidural injections with Sarapin steroids in chronic low back pain. Pain Physician 2001; 4:322-335.

37. Butterman GR. The effect of spinal steroid injections for degenerative disc disease. Spine J 2004; 4:495-505.

38. Moher D, Schulz KF, Altman D, for the CONSORT Group. The CONSORT statement: Revised recommendations for improving the quality of reports of parallel-group randomized trials. JAMA 2001; 285:1987-1991.

39. Manchikanti L, Hirsch JA, Smith HS. Evidence-based medicine, systematic reviews, and guidelines in interventional pain management: Part 2: Randomized controlled trials. Pain Physician 2008; 11:717-773.

40. Manchikanti L, Benyamin RM, Helm S, Hirsch JA. Evidence-based medicine, systematic reviews, and guidelines in interventional pain management: Part 3: Systematic reviews and meta-analysis of randomized trials. Pain Physician 2009; 12:35-72.

41. Manchukonda R, Manchikanti KN, Cash KA, Pampati V, Manchikanti L. Facet joint pain in chronic spinal pain: An evaluation of prevalence and false-positive rate of diagnostic blocks. / Spinal Disord Tech 2007; 20:539-545.

42. Manchikanti L, Singh V, Smith HS, Hirsch JA. Evidence-based medicine, systematic reviews, and guidelines in interventional pain management: Part 4: Observational studies. Pain Physician 2009; 12:73-108.

43. Manchikanti L, Datta S, Smith HS, Hirsch JA. Evidence-based medicine, systematic reviews, and guidelines in interventional pain management: Part 6. Systematic reviews and meta-analyses of observational studies. Pain Physician 2009; 12:819-850.

44. Fairbank JCT, Pynsent PB. The Oswestry disability index. Spine (Phila Pa 1976) 2000; 25:2940-2953.

45. Pereira J, Lawlor $P$, Vigano A, Dorgan $M$, Bruera E: Equianalgesic dose ratios for opioids. A critical review and proposals for long-term dosing. J Pain Symptom Manage 2001; 22:672-687.

46. Browner WS, Newman TB, Cummings SR, Hulley SB. Estimating sample size and power. In: Hulley SB, Cummings 
SR, Browner WS, Grady D, Hearst N, Newman TB (eds). Designing Clinical Research: An Epidemiologic Approach 2nd ed. Lippincott, Williams \& Wilkins, Philadelphia 2001, pp 65-84.

47. Manchikanti L, Falco FJE, Boswell MV, Hirsch JA. Facts, fallacies, and politics of comparative effectiveness research: Part I. Basic considerations. Pain Physician 2010; 13:E23-E54.

48. Manchikanti L, Falco FJE, Boswell MV, Hirsch JA. Facts, fallacies, and politics of comparative effectiveness research: Part 2 - Implications for interventional pain management. Pain Physician 2010; 13:E55-E79.

49. Manchikanti L, Datta S, Derby R, Wolfer LR, Benyamin RM, Hirsch JA. A critical review of the American Pain Society clinical practice guidelines for interventional techniques: Part 1. Diagnostic interventions. Pain Physician 2010; 13: E141-E174.

50. Manchikanti L, Datta S, Gupta S, Munglani $R$, Bryce DA, Ward SP, Benyamin RM, Sharma ML, Helm II S, Fellows B, Hirsch JA. A critical review of the American Pain Society clinical practice guidelines for interventional techniques: Part 2. Therapeutic interventions. Pain Physician 2010; 13:E215-E264.

51. Manchikanti L, Singh V, Falco FJ, Cash KA, Fellows B. Cervical medial branch blocks for chronic cervical facet joint pain: A randomized double-blind, controlled trial with one-year follow-up. Spine (Phila Pa 1976) 2008; 33:18131820.

52. Manchikanti L, Singh V, Falco FJE, Cash $K A$, Pampati V. Evaluation of lumbar facet joint nerve blocks in managing chronic low back pain: A randomized, double-blind, controlled trial with a 2-year follow-up. Int J Med Sci 2010; 7:124-135.

53. Manchikanti L, Singh V, Falco FJE, Cash KA, Fellows B. Comparative outcomes of a 2-year follow-up of cervical medial branch blocks in management of chronic neck pain: A randomized, double-blind controlled trial. Pain Physician 2010; 13:437-450.

54. Manchikanti L, Singh V, Cash KA, Pampati V, Datta S. Management of pain of post lumbar surgery syndrome: Oneyear results of a randomized, doubleblind, active controlled trial of fluoroscopic caudal epidural injections. Pain Physician 2010; 13:509-522.

55. Manchikanti L, Singh V, Cash KA, Pampati V, Damron KS, Boswell MV. Pre- liminary results of randomized, equivalence trial of fluoroscopic caudal epidural injections in managing chronic low back pain: Part 2. Disc herniation and radiculitis. Pain Physician 2008; 11:801-815.

56. Manchikanti L, Cash KA, McManus CD, Pampati V, Abdi S. Preliminary results of randomized, equivalence trial of fluoroscopic caudal epidural injections in managing chronic low back pain: Part 4. Spinal stenosis. Pain Physician 2008 11:833-848.

57. Manchikanti L, Cash KA, McManus CD, Pampati V, Singh V, Benyamin RM. The preliminary results of a comparative effectiveness evaluation of adhesiolysis and caudal epidural injections in managing chronic low back pain secondary to spinal stenosis: A randomized, equivalence controlled trial. Pain Phy sician 2009; 12:E341-E354.

58. Manchikanti L, Singh V, Cash KA, Pampati V, Datta S. A comparative effectiveness evaluation of percutaneous adhesiolysis and epidural steroid injections in managing lumbar post surgery syndrome: A randomized, equivalence controlled trial. Pain Physician 2009; 12:E355-E368.

59. Hotopf M. The pragmatic randomized controlled trial. Adv Psychiatr Treat 2002; 8:326-333.

60. Tunis SR, Stryer DB, Clancy CM. Practical clinical trials. Increasing the value of clinical research for decision making in clinical and health policy. JAMA 2003; 290:1624-1632.

61. Roland $M$, Torgerson DJ. What are pragmatic trials? BMJ 1998; 316:285.

62. International Conference on Harmonisation of Technical Requirements for Registration of Pharmaceuticals for Human Use. ICH Harmonised Tripartite Guideline. Choice of Control Group and Related Issues in Clinical Trials E10. July 20, 2000.

63. Manchikanti L, Singh V, Falco FJE. In response to Smuck $M$, Levin JH. RE: Manchikanti L, Singh V, Falco FJE, Cash KA, Fellows B. Cervical medial branch blocks for chronic cervical facet joint pain: A randomized double-blind, controlled trial with one-year follow-up. Spine (Phila Pa 1976) 2009; 34:11161117.

64. Pham Dang C, Lelong A, Guilley J, Nguyen JM, Volteau C, Venet G, Perrier C, Lejus $C$, Blanloeil Y. Effect on neurostimulation of injectates used for perineural space expansion before place- ment of a stimulating catheter: Normal saline versus dextrose $5 \%$ in water. Reg Anesth Pain Med 2009; 34:398-403.

65. Tsui BC, Kropelin B, Ganapathy S, Finucane B. Dextrose $5 \%$ in water: Fluid medium maintaining electrical stimulation of peripheral nerve during stimulating catheter placement. Acta Anaesthesiol Scand 2005; 49:1562-1565.

66. Indahl A, Kaigle AM, Reikeräs O, Holm $\mathrm{SH}$. Interaction between the porcine lumbar intervertebral disc, zygapophysial joints, and paraspinal muscles. Spine (Phila Pa 1976) 1997; 22:28342840.

67. Indahl A, Kaigle A, Reikeräs O, Holm S. Electromyographic response of the porcine multifidus musculature after nerve stimulation. Spine (Phila $\mathrm{Pa}$ 1976) $1995 ; 20: 2652-2658$.

68. Carette $S$, Leclaire R, Marcoux $S$, Morin F, Blaise GA, St-Pierre A, Truchon R, Parent $F$, Levesque J, Bergeron V, Montminy $\mathrm{P}$, Blanchette $\mathrm{C}$. Epidural corticosteroid injections for sciatica due to herniated nucleus pulposus. $N$ Engl I Med 1997; 336:1634-1640.

69. Bhatia MT, Parikh LCJ. Epidural saline therapy in lumbo-sciatic syndrome. J Indian Med Assoc 1966; 47:537-542.

70. Gupta AK, Mital VK, Azmi RU. Observations of the management of lumbosciatic syndromes (sciatica) by epidural saline. I Indian Med Assoc 1970; 54:194-196.

71. Manchikanti L. Role of neuraxial steroids in interventional pain management. Pain Physician 2002; 5:182-199.

72. Byrod G, Otani K, Brisby H, Rydevik B, Olmarker K. Methylprednisolone reduces the early vascular permeability increase in spinal nerve roots induced by epidural nucleus pulposus application. J Orthop Res 2000; 18:983-987.

73. Hayashi N, Weinstein JN, Meller ST, Lee HM, Spratt KF, Gebhart GF. The effect of epidural injection of betamethasone or bupivacaine in a rat model of lumbar radiculopathy. Spine (Phila Pa 1976) 1998; 23:877-885.

74. Lee HM, Weinstein JN, Meller ST, Hayashi N, Spratt KF, Gebhart GF. The role of steroids and their effects on phospholipase A2: An animal model of radiculopathy. Spine (Phila Pa 1976) 1998; 23:1191-1196.

75. Minamide A, Tamaki T, Hashizume H, Yoshida M, Kawakami M, Hayashi N. Effects of steroids and lipopolysaccharide on spontaneous resorption of her- 
niated intervertebral discs: An experimental study in the rabbit. Spine (Phila Pa 1976) 1998; 23:870-876.

76. Pasqualucci $A$, Varrassi $G$, Braschi $A$, Peduto VA, Brunelli $A$, Marinangeli $F$, Gori F, Colò F, Paladín A, Mojoli F. Epidural local anesthetic plus corticosteroid for the treatment of cervical brachial radicular pain: Single injection verus continuous infusion. Clin J Pain 2007; 23:551-557.

77. Ji RR, Woolf CJ. Neuronal plasticity and signal transduction in nociceptive neurons: Implications for the initiation and maintenance of pathological pain. Neurobiol Dis 2001; 8:1-10.

78. Mao J, Chen LL. Systemic lidocaine for neuropathic pain relief. Pain 2000; 87:7-17.

79. Pasqualucci A. Experimental and clinical studies about the preemptive analgesia with local anesthetics. Possible reasons of the failure. Minerva Aneste- siol 1998; 64:445-457.

80. Arner S, Lindblom U, Meyerson BA, Molander $C$. Prolonged relief of neuralgia after regional anesthetic block. A call for further experimental and systematic clinical studies. Pain 1990; 43:287297.

81. Lavoie PA, Khazen T, Filion PR. Mechanisms of the inhibition of fast axonal transport by local anesthetics. Neuropharmacology 1989; 28:175-181.

82. Cassuto J, Sinclair R, Bonderovic M. Anti-inflammatory properties of local anesthetics and their present and potential clinical implications. Acta Anaesthesiol Scand 2006; 50:265-282.

83. Melzack R, Coderre TJ, Katz J, Vaccarino AL. Central neuroplasticity and pathological pain. Ann N Y Acad Sci 2001; 933:157-174.

84. Manchikanti L, Cash KA, McManus CD, Pampati V, Benyamin RM. A preliminary report of a randomized double- blind, active controlled trial of fluoroscopic thoracic interlaminar epidural injections in managing chronic thoracic pain. Pain Physician 2010; 13:E357E369.

85. Manchikanti L, Singh V, Falco FJE, Cash KA, Pampati V, Fellows B. Comparative effectiveness of a one-year followup of thoracic medial branch blocks in management of chronic thoracic pain: A randomized, double-blind active controlled trial. Pain Physician 2010; 13:535-548.

86. Sato C, Sakai A, Ikeda Y, Suzuki H, Sakamoto A. The prolonged analgesic effect of epidural ropivacaine in a rat model of neuropathic pain. Anesth Analg 2008; 106:313-320.

87. Tachihara $\mathrm{H}$, Sekiguchi $\mathrm{M}$, Kikuchi $\mathrm{S}$, Konno S. Do corticosteroids produce additional benefit in nerve root infiltration for lumbar disc herniation. Spine (Phila Pa 1976) 2008; 33:743-747. 